\title{
MEMUTUS RANTAI INFEKSI MELALUI FUNGSI PENGORGANISASIAN KEPALA RUANG RAWAT
}

\author{
Fitriana Dewi ${ }^{1 *}$, Hanny Handiyani ${ }^{2}$, Kuntarti $^{2}$ \\ 1. Akademi Kesehatan Pemkab Aceh Utara, Kota Lhokseumawe, Aceh 24352, Indonesia \\ 2. Fakultas Ilmu Keperawatan Universitas Indonesia, Kampus UI, Depok 16424, Indonesia \\ *Email: nyanyak_ok@yahoo.co.id
}

\begin{abstract}
Abstrak
Perawat berperan penting sebagai pemutus rantai infeksi untuk menurunkan angka kejadian infeksi yang didapat di rumah sakit (HAIs). Penelitian deskriptif korelatif ini bertujuan untuk mendapatkan gambaran pengaruh karakteristik, peran kepemimpinan, dan fungsi manajemen kepala ruang terhadap perilaku perawat dalam memutus rantai infeksi. Penelitian pada 130 perawat menunjukkan faktor yang memengaruhi perilaku perawat dalam memutus rantai infeksi adalah peran interpersonal $(\mathrm{p}=0,001 ; \mathrm{OR}=7,07 ; 95 \% \mathrm{CI}, .25 ; 22,2)$, peran pengambilan keputusan $(\mathrm{p}=0,004 ; \mathrm{OR}=4,7$; $95 \%$ CI 1,7;13.0), dan fungsi pengorganisasian ( $\mathrm{p}=0,001 ; \mathrm{OR}=21,46 ; 95 \%$ CI 7,$2 ; 63,9$ ). Faktor yang paling memengaruhi perilaku perawat dalam memutus rantai infeksi adalah fungsi pengorganisasian $(p=0,001 ; O R=0,047$; 95\% CI 0,016;0,139). Kepala ruang berperan sebagai role model untuk meningkatkan pengetahuan dan keterampilan perawat untuk berperilaku baik dalam upaya pencegahan dan pengendalian infeksi di rumah sakit.
\end{abstract}

Kata kunci: fungsi manajemen, pencegahan dan pengendalian infeksi, peran kepemimpinan, perilaku perawat, rantai infeksi

\section{Abstract}

Break the Chain Infection by Organization Function Head Ward. Nurses have an important role to break the chain of infection in decreasing Healthcare Associated Infections (HAIs) in hospital. The aim of this descriptive of correlation research is to get the description of characteristic, role of leadership, and the function of head nurse management toward nurse's behavior in breaking the chain of infection. This research involves 130 nurses showed that the influencing factors of nurse's behavior (through the questionnaire) in breaking the chain of infection are the interpersonal role $(p=0.001, O R=7.07,95 \%$ CI 2.25;22.2), the decision maker role $(p=0.004, O R=4.7,95 \% C I$ 1.7;13.0), and the organizing function ( $p=0.001, O R=21.46,95 \%$ CI 7.2;63.9). The result showed that the dominant factors of the nurse's behavior in breaking the chain of infection is organizing factors of the head nurse ( $p=0.001$, $O R=0.047,95 \%$ CI 0.016;0.139). Head nurse is a role model in increasing the knowledge and skill of nurse to behave well in order to prevent and control the infection in hospital.

Keywords: leadership role, management function, nurse's behavior, prevention and infection control, the chain of infection

\section{Pendahuluan}

Healthcare Associated Infections (HAIs) merupakan infeksi yang didapat saat pasien dirawat di rumah sakit dan setelah pasien dirawat lebih dari 48 jam menerima pelayanan kesehatan (Chalmers \& Straub, 2006; JCI, 2011; WHO, 2002). Perawat merupakan tenaga kesehatan yang berhubungan langsung dengan pasien dan dapat menjadi media transmisi infeksi baik bagi perawat maupun pasien (Bartley \& Russell, 2003; Kagan, Ovadia \& Kaneti, 2009).

Perawat mencegah terjadinya infeksi dengan cara memutuskan rantai penularan infeksi (Craven \& Hirnle, 2007). Kegiatan ini berkaitan dengan perilaku perawat. Perilaku perawat 
dalam melakukan kegiatan pencegahan dan pengendalian infeksi dapat dibentuk dengan aktivitas dalam menampilkan peran dan fungsi kepala ruang sebagai pemimpin. Kepemimpinan kepala ruang dapat memengaruhi perilaku bawahannya (Robbins, 2003; Sellgren, Ekval, \& Tomson, 2006).

Manajemen kepala ruang sangat penting dalam menunjang program pencegahan dan pengendalian infeksi di rumah sakit. Salah satu fungsi manajemen adalah pengorganisasian, dimana kepala ruang hendaknya mengembangkan organisasi keperawatan secara objektif sehingga memudahkan perawat dalam melaksanakan asuhan keperawatan khususnya upaya pencegahan dan pengendalian infeksi. Perilaku perawat dapat ditunjukkan dengan peningkatan kinerja dan kepatuhan perawat dalam melakukan kegiatan pencegahan dan pengendalian infeksi. Efstathiou, Papastavrou, Raftopoulos, dan Merkouris (2011) menyatakan perubahan perilaku perawat dipengaruhi oleh pengetahuan dan kepatuhan perawat terhadap pelaksanaan standard precaution. Studi dokumentasi menyebutkan angka infeksi di RSUD Cut Meutia Aceh Utara pada tahun 2011 sebagai berikut: Infeksi Aliran Darah Primer (IADP)/flebitis 2,42\%, Infeksi Daerah Operasi (IDO) $1,21 \%$, Infeksi Saluran Kemih (ISK) $0,34 \%$, dan luka dekubitus $0,17 \%$

\section{Metode}

Pengambilan sampel dengan menggunakan systematic random sampling. Instrumen pengumpulan data adalah kuesioner dan lembar observasi yang dikembangkan peneliti berdasarkan pedoman pencegahan infeksi di rumah sakit (Kemenkes RI, 2011). Sebelum penelitian, kuesioner dilakukan uji validitas dan realibilitas di RSU dr. Fauziah Bireun Aceh, yang didapatkan hasil uji kuesioner B hasil $r$ hitung $0.371-0.68$ dengan $\alpha$ cronbach 0,838 sedangkan kuesioner $\mathrm{C}$ hasil $\mathrm{r}$ hitung $0.374-0.74$ dengan $\alpha$ cronbach 0.923 . Hasil uji inter rater reliability didapat nilai Kappa $>0.730-0.865$.

\section{Hasil}

Hasil pada gambar 1 menunjukkan 106 orang yang berperilaku baik pada pengambilan kuesioner dan pada saat observasi hanya 45 orang yang berperilaku baik.

Tabel 1 menunjukkan adanya hubungan yang bermakna antara peran interpersonal kepala ruang dengan perilaku perawat dalam memutus rantai infeksi ( $p=0,001, \alpha=0,05)$.

Hasil analisis menemukan nilai $\mathrm{OR}=7,07$ (95\% CI 2,25;22,2), artinya kepala ruang yang menerapkan peran interpersonal dengan baik mempunyai peluang 7,07 kali meningkatkan perilaku perawat dalam memutus rantai infeksi dibandingkan dengan kepala ruang yang menerapkan peran interpersonal dengan kurang baik.

Ada hubungan bermakna antara peran pengambilan keputusan kepala ruang dengan perilaku perawat dalam memutus rantai infeksi $(\mathrm{p}=0,004, \alpha=0,05)$. Hasil analisis diperoleh nilai OR=4,7 (95\% CI 1,7;13,0), artinya kepala ruang yang menerapkan peran pengambilan keputusan dengan baik mempunyai peluang 4,7 kali meningkatkan perilaku perawat dalam memutus rantai infeksi dibandingkan dengan kepala ruang yang menerapkan peran pengambilan keputusan kurang baik.

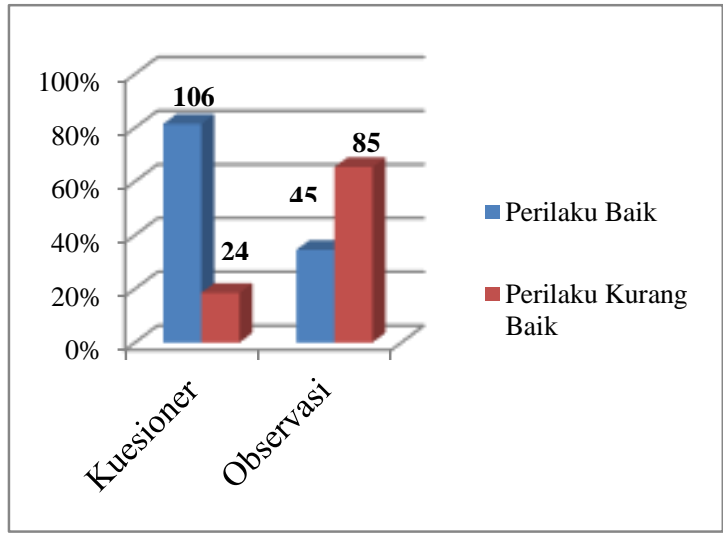

Gambar 1. Perilaku Perawat dalam Memutus Rantai Infeksi di Rumah Sakit 
Tabel 1. Hubungan Peran Kepemimpinan dan Fungsi Manajemen Kepala Ruang Menurut Persepsi Perawat dengan Perilaku Perawat dalam Memutus Rantai Infeksi

\begin{tabular}{|c|c|c|c|c|c|c|c|c|}
\hline \multirow{3}{*}{ Variabel } & \multicolumn{4}{|c|}{ Perilaku (kuesioner) } & \multirow{2}{*}{\multicolumn{2}{|c|}{ Total }} & \multirow{3}{*}{$\mathbf{p}$} & \multirow{3}{*}{ OR $(95 \% \mathrm{CI})$} \\
\hline & \multicolumn{2}{|c|}{ Baik } & \multicolumn{2}{|c|}{ Kurang baik } & & & & \\
\hline & $\mathbf{n}$ & $\%$ & $\mathbf{n}$ & $\%$ & $\mathbf{N}$ & $\%$ & & \\
\hline \multicolumn{9}{|l|}{ Peran interpersonal } \\
\hline a. Baik & 99 & 86,1 & 16 & 13,9 & 115 & 100 & $0,001^{*}$ & 7,07 \\
\hline b. Kurang baik & 7 & 46,7 & 8 & 53,3 & & 100 & & $2,25-22,2$ \\
\hline \multicolumn{9}{|l|}{ Peran informasional } \\
\hline a. Baik & 90 & 84,9 & 16 & 15,1 & 106 & 100 & 0,76 & 2,8 \\
\hline b. Kurang baik & 16 & 66,7 & 8 & 33,3 & & 100 & & $1-7,67$ \\
\hline \multicolumn{9}{|l|}{ Peran pengambilan } \\
\hline keputusan & & & & & & & $0,004^{*}$ & 4,7 \\
\hline a. Baik & 94 & 86,2 & 15 & 13,8 & 109 & 100 & & $1,7-13,0$ \\
\hline b. Kurang baik & 12 & 57,1 & 9 & 42,9 & & 100 & & \\
\hline \multicolumn{9}{|l|}{ Fungsi perencanaan } \\
\hline a. Baik & 98 & 83,8 & 19 & 16,2 & 117 & 100 & 0,064 & 3,2 \\
\hline b. Kurang baik & 8 & 61,5 & 5 & 38,5 & & 100 & & $0,95-10,9$ \\
\hline \multicolumn{9}{|c|}{ Fungsi pengorganisasian } \\
\hline a. Baik & 93 & 93,9 & 6 & 6,1 & 99 & 100 & $0,001^{*}$ & 21,46 \\
\hline b. Kurang baik & 13 & 41,9 & 18 & 58,1 & 31 & 100 & & $7,2-63,9$ \\
\hline \multicolumn{9}{|l|}{ Fungsi ketenagaan } \\
\hline a. Baik & 66 & 85,7 & 11 & 14,3 & 77 & 100 & 0,212 & 1,95 \\
\hline b. Kurang baik & 40 & 75,5 & 13 & 24,5 & 53 & 100 & & $0,798-4,77$ \\
\hline \multicolumn{9}{|l|}{ Fungsi pengarahan } \\
\hline a. Baik & 56 & 80,0 & 14 & 20,0 & 70 & 100 & 0,794 & 0,8 \\
\hline b. Kurang baik & 50 & 83,3 & 10 & 16,7 & 60 & 100 & & $0,326-1,96$ \\
\hline \multicolumn{9}{|l|}{ Fungsi pengendalian } \\
\hline a. Baik & 69 & 85,2 & 12 & 14,8 & 81 & 100 & 0,252 & 1,86 \\
\hline b. Kurang & 37 & 75,5 & 12 & 24,5 & 49 & 100 & & $0,76-4,56$ \\
\hline
\end{tabular}

Keterangan: *bermakna pada $\alpha<0,05$

Tabel 2. Hubungan Karakteristik Perawat dengan Perilaku Perawat dalam Memutus Rantai Infeksi

\begin{tabular}{|c|c|c|c|c|c|c|c|c|}
\hline \multirow{3}{*}{ Variabel } & \multicolumn{4}{|c|}{ Perilaku (observasi) } & \multirow{2}{*}{\multicolumn{2}{|c|}{ Total }} & \multirow{3}{*}{$\mathbf{p}$} & \multirow{3}{*}{ OR $(95 \% \mathrm{CI})$} \\
\hline & \multicolumn{2}{|c|}{ Baik } & \multicolumn{2}{|c|}{ Kurang baik } & & & & \\
\hline & $\mathbf{N}$ & $\%$ & $\mathbf{N}$ & $\%$ & $\mathbf{N}$ & $\%$ & & \\
\hline \multicolumn{9}{|l|}{ Usia } \\
\hline a. $\geq 28$ tahun & 22 & 33,3 & 44 & 66,7 & 66 & 100 & 0,898 & 0,891 \\
\hline b. $<28$ tahun & 23 & 35,9 & 41 & 64,1 & 64 & 100 & & $0,433-1,837$ \\
\hline \multicolumn{9}{|l|}{ Jenis Kelamin } \\
\hline a. Laki-laki & 18 & 42,9 & 24 & 57,1 & 42 & 100 & 0,243 & 0,590 \\
\hline b. Perempuan & 27 & 30,7 & 61 & 69,3 & 88 & 100 & & $0,276-1,263$ \\
\hline \multicolumn{9}{|l|}{ Masa kerja } \\
\hline a. $\geq 4$ tahun & 31 & 34,8 & 58 & 62,5 & 89 & 100 & 1,000 & 1,031 \\
\hline b. $<4$ tahun & 14 & 34,1 & 27 & 65,9 & 41 & 100 & & $0,473-2,246$ \\
\hline \multicolumn{9}{|l|}{ Pendidikan } \\
\hline a. Profesional & 4 & 50,0 & 4 & 50,0 & 8 & 100 & 0,447 & 1,976 \\
\hline b. Vokasional & 41 & 33,6 & 81 & 66,4 & 122 & 100 & & $0,470-8,304$ \\
\hline \multicolumn{9}{|l|}{ Pelatihan } \\
\hline a. Pernah & 27 & 45,8 & 32 & 54,2 & 18 & 100 & $0,024^{*}$ & 2,484 \\
\hline b. Belum pernah & 18 & 25,4 & 53 & 74,6 & 71 & 100 & & $1,185-5,209$ \\
\hline
\end{tabular}

Keterangan: *bermakna pada $\alpha<0,05$ 
Ada hubungan bermakna antara fungsi pengorganisasian kepala ruang dengan perilaku pera-wat dalam memutus rantai infeksi $(\mathrm{p}=$ $0,001, \alpha=0,05)$. Hasil analisis diperoleh nilai $\mathrm{OR}=21,46(95 \%$ CI 7,2;63,9), artinya kepala ruang yang menerapkan fungsi pengorganisasian dengan baik mempunyai peluang 21,46 kali meningkatkan perilaku perawat dalam memutus rantai infeksi dibandingkan dengan kepala ruang yang menerapkan fungsi pengorganisasian kurang baik.

Hasil penelitian untuk karakteristik perawat didapatkan gambaran usia perawat terbanyak adalah > 28 tahun (66 orang), jenis kelamin perempuan (88 orang), masa kerja $\geq 4$ tahun (89 orang) pendidikan vokasional (122 orang) dan perawat belum mengikuti pelatihan tentang infeksi (71 orang).

Perawat yang pernah mengikuti pelatihan memiliki perilaku baik dalam memutus rantai infeksi lebih banyak dibandingkan dengan perawat yang belum pernah mengikuti pelatihan tentang infeksi $(45,8 \%)$. Hasil uji statistik menunjukkan ada hubungan antara pelatihan dengan perilaku perawat dalam memutus rantai infeksi $(p=0,024 ; \alpha=0,05)$. Hasil analisis diperoleh nilai $\mathrm{OR}=2,484(95 \%$ CI 7,$2 ; 63,9)$, artinya perawat yang pernah mengikuti pelatihan tentang pencegahan dan pengendalian infeksi mempunyai peluang 2,484 kali berperilaku baik dibandingkan perawat yang belum pernah mengikuti pelatihan. Hasil analisis untuk uji multivariat didapatkan faktor yang paling berpengaruh terhadap perilaku perawat dalam memutus rantai infeksi berdasar hasil kuesioner adalah fungsi pengorganisasian.

\section{Pembahasan}

Hasil analisis perilaku diukur dengan dua alat pengukuran data yaitu kuesioner dan lembar observasi. Untuk gambaran perilaku berdasarkan kuesioner didapatkan hasil mayoritas perawat berperilaku baik. Perilaku yang diukur melalui observasi menunjukkan mayoritas perawat berperilaku kurang baik dalam memu- tuskan rantai infeksi. Perilaku perawat merupakan proses interaksi antar individu dengan lingkungannya, dalam hal ini lingkungan kerja (Rivai \& Mulyadi, 2003). Kepala ruang dituntut untuk dapat meningkatkan kemampuan perawat dalam memperbaiki perilaku yang dapat diukur melalui kognitif, afektif, dan psikomotor.

Perilaku yang didapatkan melalui kuesioner menggambarkan persepsi perawat terhadap perilakunya dalam melaksanakan kegiatan pelayanan keperawatan. Sedangkan perilaku yang didapatkan melalui observasi adalah perilaku yang ditampilkan perawat pada saat melakukan kegiatan keperawatan. Perbedaan hasil yang signifikan dapat disebabkan oleh beberapa hal antara lain kemampuan kognitif perawat sudah baik dalam mengisi kuesioner, perawat lebih subjektif menilai perilakunya sendiri dan lain-lain, namun tidak dibarengi dengan perilaku yang ditampilkan. Penelitian yang dilakukan Cason, Tyner, Sue, dan Broome (2007) berdasarkan hasil kuesioner, didapatkan $90 \%$ perawat melakukan kebersihan tangan, namun pada saat diobservasi hanya $22 \%$ perawat yang benar-benar melakukan kebersihan tangan.

Kemampuan perawat untuk berperilaku baik tidak lepas dari tampilan perilaku kepala ruangannya. Kepala ruang berusaha menerapkan gaya kepemimpinan yang dapat membuat bawahannya berperilaku sesuai dengan yang diharapkan (Hogg \& Vaughan, 2002).

Hal ini sejalan dengan penjelasan Marquis dan Huston (2010) yang menyebutkan bahwa manajer berupaya menciptakan suasana yang memotivasi dalam mencapai tujuan staf dan organisasi. Pemimpin juga berfungsi sebagai model peran, pendengar, pemberi dukungan dan pemberi semangat bagi pegawai yang kurang termotivasi. Kepala ruang merupakan kunci utama dalam mewujudkan tujuan organisasi yang dipimpinnya, khususnya dalam menjalankan fungsi pengawasan untuk mengendalikan mutu pelayanan. 
Hasil penelitian menunjukkan perawat yang berusia lebih besar sama dengan 28 tahun berperilaku lebih baik dari perawat yang berusia kurang dari 28 tahun. Data ini mendukung penelitian yang dilakukan Lammintakanen dan Kivinen (2012) yang menyatakan bahwa perawat yang berusia lebih tua akan memiliki keterampilan, pengalaman, dan pengetahuan yang lebih baik dari pada perawat yang berusia lebih muda. Namun berbeda dengan hasil observasi yang menemukan bahwa perawat yang berusia kurang dari 28 tahun menunjukkan perilaku lebih baik daripada perawat yang berusia lebih besar sama dengan 28 tahun. Robbins (2003) menyebutkan usia 2040 tahun merupakan tahap perkembangan dewasa muda dimana seseorang berada dalam kondisi perkembangan puncak dari kondisi fisik sehingga dapat mengaplikasikan ilmu pengetahuan dan keterampilan yang dimiliki untuk mencegah kejadian infeksi di rumah sakit.

Variabel jenis kelamin menunjukkan bahwa mayoritas perawat adalah perempuan. Data ini menjelaskan bahwa profesi keperawatan lebih banyak diminati oleh perempuan. Penelitian yang sama juga menyebutkan perempuan lebih mendominasi profesi keperawatan daripada laki-laki. Hal ini disebabkan perempuan lebih bersifat caring daripada laki-laki (Rochlen, Good, \& Carver, 2009). Hasil studi ini juga menemukan bahwa perempuan lebih menunjukkan wajah ekspresif, mempertahankan kontak mata, dan sentuhan dalam melakukan kegiatan. Perempuan dapat berkomunikasi verbal lebih baik dibandingkan laki-laki (Arnold \& Boggs, 2007). Hasil analisis bivariat perilaku berdasarkan kuesioner diperoleh perawat perempuan berperilaku lebih baik daripada laki-laki. Hal ini dapat dijelaskan bahwa profesi keperawatan merupakan pilihan untuk menentukan karir seseorang yang kecenderungan perempuan yang mendominasi pilihan tersebut.

Variabel masa kerja menggambarkan bahwa kebanyakan perawat di RSUD Cut Meutia
Aceh Utara bekerja lebih besar sama dengan 4 tahun. Hasil penelitian Ellis (2006) menyatakan perawat yang mempunyai pengalaman kerja yang cukup akan dapat mengerti kebutuhan pasien yang spesifik. Hasil analisis bivariat diperoleh perawat yang bekerja lebih besar sama dengan 4 tahun berperilaku lebih baik dari perawat yang bekerja kurang dari 4 tahun. Sedangkan hasil observasi menunjukkan adanya proporsi yang hampir berimbang untuk perawat yang masa kerjanya kurang dari 4 tahun dan lebih besar sama dengan 4 tahun. Lamanya waktu kerja seseorang akan membentuk perilaku yang sesuai sebagaimana yang diharapkan. Hasil penelitian mendapatkan bahwa perawat yang bekerja lebih dari empat tahun lebih baik perilakunya. Individu yang telah melampaui masa kerja yang cukup lama akan mempunyai pengalaman yang lebih banyak sehingga memengaruhi perilaku yang ditampilkan. Semakin lama seseorang bekerja di bidang pelayanan klinis maka akan semakin baik pula penampilan kerja yang ditunjukkan (Swansburg, 2002; Siagian, 2009).

Variabel pendidikan didominasi oleh perawat yang berpendidikan vokasional (SPK dan D3 keperawatan). Data Kementerian Kesehatan RI (2011) menyebutkan bahwa mayoritas tenaga keperawatan Indonesia didominasi lulusan D3 Keperawatan. Tingkat pendidikan merupakan salah satu karakteristik perawat yang dapat ditingkatkan melalui kegiatan pembelajaran dan pengetahuan, sehingga dapat membentuk perilaku baik dalam pencegahan dan pengendalian infeksi. Perawat yang berpendidikan profesional mayoritas berperilaku baik dibandingkan perawat yang berpendidikan vokasional. Karakteristik terakhir adalah pelatihan tentang infeksi yang pernah diikuti oleh perawat dimana didapatkan kebanyakan perawat di RSUD Cut Meutia pernah mengikuti pelatihan tentang pencegahan dan pengendalian infeksi. Pelatihan merupakan proses pembelajaran nonformal aplikatif yang bertujuan untuk meningkatkan kemampuan dan keterampilan khusus bagi perawat (Notoatmodjo, 2010). Pihak rumah sakit pernah melakukan pelatihan ten- 
tang pencegahan dan pengendalian infeksi bagi perawat, namun belum semua perawat mengikuti pelatihan tersebut. Pelatihan yang efektif merupakan kunci untuk meningkatkan profesionalisme perawat dalam melaksanakan tugasnya (Chen, Beck, \& Amos, 2005).

Mayoritas perawat mempersepsikan kepala ruangan telah menerapkan peran interpersonal dengan baik, sehingga menghasilkan perilaku baik perawat dalam memutus rantai infeksi. Hal ini dapat menjelaskan bahwa kepala ruang di RSUD Cut Meutia Aceh Utara telah melaksanakan peran interpersonal yang seharusnya dilaksanakan. Kemampuan melaksanakan peran ini dapat juga ditunjukkan dengan kemampuan berkomunikasi yang baik meliputi kemampuan mendengar, mengamati, mengarahkan, dan mengevaluasi kinerja perawat yang ditunjukkan melalui perilaku (Venturato \& Drew, 2010).

Kepala ruang merupakan manajer lini pertama yang berperan untuk mendukung perawat dalam berperilaku baik terhadap pencegahan dan pengendalian infeksi. Kompetensi kepala ruang dalam melaksanakan peran interpersonal tidak terlepas dari kemampuan kognitif, perilaku yang ditunjukkan, dan budaya kerja dari kepala ruang itu sendiri. Kepala ruang hendaknya menyadari bahwasanya ia menjadi role model bagi stafnya (Arnold \& Boggs, 2007).

Mayoritas perawat mempersepsikan kepala ruangan telah menerapkan peran informasional dengan baik sehingga cenderung berperilaku baik. Komunikasi merupakan salah satu faktor yang berperan penting yang harus dimiliki oleh kepala ruang dalam pemberian tugas kepada perawat di ruangan sehingga perawat dapat memahami sepenuhnya apa yang menjadi kewajiban dan hak-nya. Kesalahan dalam pemberian informasi dapat menyebabkan kesalahan interpretasi sehingga berdampak pada pembentukan perilaku yang kurang baik. Perilaku perawat dalam upaya pencegahan dan pengendalian infeksi dapat berupa kegiatan membersihkan tangan yang dilakukan dengan benar dan penggunaan alat pelindung diri.
Kepala ruang sebagai pimpinan mempunyai peran penting dalam penyelesaian masalah dan pengambilan keputusan berkaitan dengan kepentingan bawahannya. Selain itu, kepala ruang juga berperan untuk menentukan arah tujuan organisasi yang ingin dicapai. Oleh karena itu diperlukan kemampuan kepala ruang melakukan pendelegasian tugas dan wewenang khususnya terkait dengan kegiatan pencegahan dan pengendalian infeksi di rumah sakit (Siagian, 2010). Analisis data diperoleh nilai $\mathrm{OR}=4,7$ artinya kepala ruang yang menerapkan peran pengambilan keputusan dengan baik mempunyai peluang 4,7 kali dalam meningkatkan perilaku staf perawat dibandingkan dengan kepala ruang yang menerapkan peran pengambilan keputusan yang kurang baik.

Data menunjukkan perawat mempersepsikan kepala ruang telah mampu melaksanakan fungsi perencanaan dengan baik. Berkaitan dengan upaya pencegahan dan pengendalian infeksi kepala ruang menyediakan fasilitas, sarana, dan prasarana yang mendukung pelaksanaan kegiatan keperawatan di ruangan sedangkan pimpinan rumah sakit menyediakan sumber daya yang memadai untuk mendukung program pencegahan dan pengendalian infeksi. Perencanaan merupakan acuan dasar bagi staf dalam melaksanakan tugasnya memberi pelayanan keperawatan. Bila kepala ruang dapat merencanakan kegiatan pencegahan dan pengendalian infeksi dengan baik maka akan memberikan dampak positif bagi perilaku perawat dalam mencegah terjadinya infeksi (HAIs) baik bagi perawat maupun pasien (JCI, 2011). Selain itu, kegiatan pencegahan dan pengendalian infeksi hendaknya menjangkau setiap bagian dari tenaga kesehatan/non kesehatan yang ada di rumah sakit seperti tenaga laundry, gizi, laboratorium, farmasi, dan lainlain.

Pengorganisasian adalah fungsi kedua dari fungsi manajemen. Kegiatan yang dilakukan pada pengorganisasian adalah membuat struktur formal yang dapat dijadikan sebagai wewenang batas pengambilan keputusan. Struktur 
organisasi ini dapat membantu melaksanakan kegiatan dalam upaya pencegahan dan pengendalian infeksi. Pengorganisasian juga menyiapkan untuk pengembangan kebijakan, prosedur, dan pembagian tugas kepada bawahan (Cherry \& Jacob, 2011). Kepala ruang sebagai manajer tertinggi di ruangan hendaknya menetapkan salah satu stafnya untuk bertugas dan bertanggung jawab dalam kegiatan pencegahan dan pengendalian infeksi di rumah sakit. Kepala ruang hendaknya dapat memberdayakan staf melalui proses interaktif yang membentuk, membangun, dan meningkatkan kerjasama (Marquis \& Huston, 2010). Manajemen rumah sakit berkontribusi dalam menentukan pelaksanaan kegiatan pencegahan dan pengendalian infeksi di rumah sakit. Iklim kerja yang nyaman juga ikut memengaruhi kinerja dan pembentukan perilaku staf. Indikator yang digunakan untuk mengukur kenyamanan yaitu kenyamanan fisik, kenyamanan mental, dan kesejahteraan. Perawat yang bekerja dalam kondisi tertekan cenderung menampilkan perilaku kurang baik yang akan berdampak pada pemberian pelayanan keperawatan bagi pasien (Zahavy, 2008). Pelaksanaan fungsi pengendalian dengan baik akan memberikan dampak positif bagi upaya kegiatan pencegahan dan pengendalian infeksi sesuai dengan perencanaan yang telah ditetapkan sehingga pelayanan yang diberikan akan lebih efektif dan efisien. Kepala ruang dapat mengevaluasi kinerja staf melalui observasi langsung maupun laporan yang dihasilkan dalam kurun waktu tertentu. Mutu pelayanan kesehatan yang optimal dapat tercipta berkat kerjasama dan kontribusi berbagai pihak yang bekerja didalamnya. Kontribusi tenaga keperawatan menjadi hal penting dalam sistem kesehatan untuk mendukung secara efektif menyediakan pelayanan kesehatan yang bermutu pada seluruh masyarakat.

Pada hasil multivariat didapatkan bahwa variabel yang paling berpengaruh adalah fungsi pengorganisasian. Pemimpin yang efektif dapat memengaruhi bawahannya untuk bekerja sesuai dengan tujuan organisasi. Peran kepemimpinan mempunyai andil penting dalam perubahan perilaku perawat. Pelaksanaan peran kepemimpinan berkaitan dengan pelaksanaan fungsi manajemen kepala ruang. Salah satu fungsi manajemen adalah fungsi pengorganisasian yang berpengaruh terhadap perubahan perilaku perawat dalam memutus rantai infeksi. Pengorganisasian adalah proses pengelompokan orang-orang dengan kewenangan dan tanggung jawab yang seimbang dan sesuai dengan rencana operasional sehingga suatu organisasi dapat digerakkan sebagai suatu kesatuan dalam rangka mencapai tujuan yang telah ditetapkan (Marquis \& Huston 2010). Kepala ruang sebagai manajer bertanggung jawab untuk meningkatkan kompetensi perawat khususnya kompetensi dalam kegiatan pencegahan dan pengendalian infeksi. Peningkatan kompetensi dapat dilakukan dengan pendidikan formal dan non formal. Kompetensi yang dimiliki dapat berupa tingkat pengetahuan dan keterampilan perawat dalam memberikan pelayanan keperawatan (Cusack \& Smith, 2010).

\section{Kesimpulan}

Perilaku perawat berdasarkan kuesioner mayoritas baik namun berdasarkan observasi mayoritas perawat berperilaku kurang baik dalam memutus rantai infeksi. Peran interpersonal, peran pengambilan keputusan, dan fungsi pengorganisasian merupakan variabel yang mempunyai hubungan bermakna dengan perilaku perawat (berdasarkan kuesioner) dalam memutus rantai infeksi. Pelatihan merupakan variabel yang mempunyai hubungan bermakna dengan perilaku perawat (berdasarkan observasi) dalam memutus rantai infeksi. Faktor yang paling dominan memengaruhi perilaku perawat (berdasarkan kuesioner) dalam memutus rantai infeksi adalah fungsi pengorganisasian (RR, KN, NN)

\section{Referensi}

Arnold, E.C., \& Boggs, K.U. (2007). Interpersonal relationships: Professional communication 
skills for nurses. Fifth Edition. Saunders Elsevier

Bartley, J \& Russell (2003). Are health care facilities safe for patient care? Healthcare Purchasing News

Cason, CL., Tyner, T, Sue, S, \& Broome, 1 (2007). Nurses' implementation of guidelines for ventilator-associated pneumonia from the center for disease control and prevetion. American journal of critical care. Diperoleh dari http://ajcc.aacnjournals.org/content/16/1 /28.long

CDC (2010). Handhygiene infection control. http://www.cdc.gov/ handhygiene/

Chalmers, C., \& Straub,. (2006). Standard principles for preventing and controlling infection. Nursing Standard. ProQuest Nursing \& Allied Health Source. doi: 10.7748/ns2006.02.20.23.57.c4071

Chen, H.C., Beck, S.L., \& Amos, L.K. (2005). Leadership styles and nursing faculty job satisfaction in taiwan. Journal of Nursing Scholarship. doi: 10.1111/j.1547-5069.2005.0 0064.x

Cherry, B \& Jacob, S.R (2011) Contemporary Nursing; Issues, trends and management. St. Louis Missouri: Elsevier

Cusack, \& Smith, M. (2010). Power Inequalities in the Assessment of Nursing Competency Within the Workplace: Implications for Nursing Management. The Journal of Continuing Education in Nursing Vol 41, No 9. doi:10.3928/00220124-0100601-07

Craven, R.F., \& Hirnle, C.J. (2007) Fundamentals of nursing human health and function. Fifth edition. Philadelphia: Lippincot Williams \& Wilkins Inc

Efstathiou, G., Papastavrou, E., Raftopoulos, V., \& Merkouris, A. (2011) Factors influencing nurses' compliance with standard precautions in order to avoid occupational exposure to microorganisms: A focus group study. BMC Nursing. Diperoleh dari http://bmcnurs.biomed central.com/articles/10.1186/1472-6955-10-1
Gillies, D.A. (2006) Manajemen keperawatan: suatu pendekatan sistem (Penerjemah: D. Sukmana \& R.W Sukmana). Jakarta: WB. Saunders Company

Ellis, et al., (2006). Staffing for safety: A synthesis of the evidence on nurse staffing and patient safety. Ottawa: Ontario

Hogg, M.A., \& Vaughan, G.M. (2002). Social Pschology. Third Edition. Pearson Education. Prentice Hall

Joint Comission International. (2011). Accreditation standard for hospital. 4th Edition. Oarkbrook Terrace-Illinois: Department of Publication Joint Comission Resources

Kagan, I, Ovadia, KL, \& Kaneti, T (2009). Perceived knowledge of blood borne pathogens and avoidance of contact with infected patient. Journal of Nursing Scholarship. doi: 10.1111/j.1547-5069.2009.0 1246.x

Kementerian Kesehatan RI. (2011). Pedoman pelaksanaan pencegahan dan pengendalian infeksi di rumah sakit dan fasilitas pelayanan kesehatan lainnya. Jakarta

Marquis, BL \& Huston, CJ. (2010). Kepemimpinan dan manajemen keperawatan: Teori \& aplikasi (Penerjemah: S. Widyawati) 4th ed. Philadelphia: Lippincot Williams \& Wilkins Inc

Rivai, V. \& Mulyadi, D. (2010) Kepemimpinan dan perilaku organisasi. Jakarta: PT. Raja Grafindo Persada

Rochlen, A.B., Good, G.E, \& Carver, T.A. (2009). Predictors of gender-related barriers, work, and life satisfaction among men in nursing. Journal of American Psychological Association doi: 10.1037/a0013291

Robbins, S.P. (2003). Organizational behavior, Tenth Edition. New Jersey: Person Education Inc 
Sellgren, S., Ekval., \& Tomson, G. (2006). Leadership styles in nursing management: preferred and perceived. Volume 14

Siagian, S.P. (2010). Teori dan praktek kepemimpinan. Jakarta: Rineka Cipta

Swansburg, R.C., \& Swansburg, J.R (2002). Introductory management and leadership for nurses. 2nd Edition. Toronto: Jones and Barlett Publisher

Venturato, L \& Drew, L. (2010). Beyond "doing": Supporting clinical leadership and nursing practice in aged care through innovative models of care. Journal Contemporary Nurse.
Vol 35 Issue 2. doi: http://dx.doi.org/10.5172 /conu.2010.35.2.157

WHO. (2002). Prevention of Hospital-Acquired Infections A Practical Guide 2nd edition. Departement of Communicable Disease, Surveilance and Response.Page 61-62. USA. Diperoleh dari http://apps.who.int/medici nedocs/documents/s16355e/s16355e.pdf

Zahavy, A.D (2008). Workplace Health Friendliness: A Cross-Level Model for Predicting Workers' Health. Journal of Occupational Health Psychology. Vol. 13, No. 3, 197-213. doi: 10.1037/1076-8998.13.3.197 